\title{
Religião ioruba, arquétipo materno e gênero maravilhoso em Kiriku e a feiticeira e A árvore da chuva
}

Camila Bastos Lopes da Silva camilabastos 19@yahoo.com.br Universidade da Amazônia (UNAMA), Pará, Belém, Brasil.

\section{Carla Regina Santos Paes} paes.c@globo.com Universidade da Amazônia (UNAMA), Pará,Belém, Brasil.

\section{José Guilherme de Oliveira} Castro

igpsico.letras@gmail.com Universidade da Amazônia (UNAMA) Pará, Belém, Brasil.

\section{RESUMO}

O presente artigo teve como intuito discutir os contos Kiriku e a feiticeira e A árvore da chuva com base nas teorias de Jung e seu conceito de arquétipo (2002), Iwashita (1991) e Ford (2000) com os conceitos de Grande Deusa e a mitologia africana, Mircea Eliade (2000; 2007) e os conceitos sobre religião e simbolismo, assim como o estudo de símbolos maternos, tais como água e árvore, entre outros, no intuito de averiguar a mitologia africana incorporada nos contos em análise, assim como a imagem de arquétipos, principalmente $o$ arquétipo materno que se transfigura nas narrativas como traço fundamental para a formação do herói que naturalmente age por meio do gênero maravilhoso nos contos. $O$ estudo é de caráter qualitativo e analisa também a teoria do gênero maravilhoso com base nos estudos de Irlemar Chiampi (1980) e de Marçal (2010). Portanto, a importância da pesquisa se deve ao fato de discutir temáticas afro-brasileiras tão importantes para o aumento do acervo histórico e cultural em nosso dia-a-dia, a partir de obras infanto-juvenis que aprofundam nosso conhecimento sobre a África e sua diversidade cultural.
\end{abstract}

PALAVRAS-CHAVE: Mito. Cultura africana. Gênero maravilhoso. Contos. 


\section{INTRODUÇÃO}

O conto Kiriku e a feiticeira incorpora a mitologia africana em sua narrativa, uma vez que, para (FORD, 2000, p. 210) na África, as divindades são adoradas principalmente "como entidades fora do indivíduo, símbolos representantes das forças básicas da vida que são sentidas como partes do self individual". Nesse contexto, para (ELIADE, 2000, p. 7) "o mito é considerado uma história sagrada e, portanto, uma história verdadeira, porque sempre se refere a realidades". Os mitos, para o autor, constituem a história dos atos dos entes sobrenaturais, representam uma história verdadeira e sagrada e, também, referem-se sempre a uma criação, contando como algo veio à existência.

[...] o mito designa [...] uma "história verdadeira" e [...] extremamente preciosa por seu caráter sagrado, exemplar e significativo. [...] O mito é uma realidade cultural e extremamente complexa, que pode ser abordada e interpretada através de perspectivas múltiplas e complementares. [...] o mito conta uma história sagrada; ele relata um acontecimento ocorrido no tempo primordial, o tempo fabuloso do "princípio". [...] Os mitos revelam, portanto, sua atividade criadora e desvendam a sacralidade (ou simplesmente a "sobrenaturalidade") de suas obras. Em suma, os mitos descrevem as diversas, e algumas vezes dramáticas, irrupções do sagrado (ou do "sobrenatural") no Mundo. É essa irrupção do sagrado que realmente fundamenta o mundo e o converte no que é hoje. E mais: é em razão das intervenções dos Entes Sobrenaturais que o homem é o que é hoje, um ser mortal, sexuado e cultural (ELIADE, 2000, p. 7-11).

O conto Kiriku e a feiticeira narra a estória de Kiriku, um menino que desde criança incorpora o mito do herói que enfrenta grandes desafios para salvar seu povo do domínio de Karabá, "a feiticeira". A história do guerreiro Kiriku se intertextualiza com a lenda de Kimanaueze, um herói cultural entre os ambundus de Angola. Diz a lenda que Kimanaueze, o velho, gerou um filho também chamado Kimanaueze. Um dia o velho disse para seu filho negociar em Luanda. Quando ele foi os makishis (ogros) saquearam a casa da família, porém, sua mulher foi a única sobrevivente. A mulher engravidou e quando chegou o dia do parto ouviu vozes saindo de sua barriga e dizendo.

Mãe, aí vem minha espada. Mãe, aí vem minha faca. Mãe, aí vem minha kilembe (planta mítica, "árvore da vida" que passa a existir com o nascimento de uma pessoa e assim, o destino da kilembe reflete a vida do indivíduo). Mãe, aí vem meu bastão. Mãe, aguente firme, aí vou eu (FORD, 2000, p. 63).

O episódio da lenda acima reflete o nascimento mítico de Kiriku que veio ao mundo sem o auxílio da mãe. Ao nascer, Kiriku lavou-se sozinho e logo caminhou rumo ao combate para deter o poder de Karabá, a "feiticeira". O surgimento de Kiriku se intertextualiza com o nascimento do filho de Kimanaueze que ao nascer veio ao mundo dizendo: "Eu sou Sudika-nbambi. No chão ponho meu bastão. No céu ponho meu antílope" (FORD, 2000, p. 63). O caráter de herói também se relaciona à personalidade de Kiriku que logo após nascer foi ao encontro do tio para guerrear contra Karabá. 
O filho de Kimanaueze, na lenda, ao nascer também diz: "Minha kilembe, fique-a no fundo da casa" (FORD, 2000, p. 64). Depois perguntou para a mãe por que o olhava daquela maneira e ela disse: "Como pode a criança que acabo de dar à luz estar falando"? Sudika nbambi responde, "não se espante, você verá todas as coisas milagrosas que irei fazer". Logo depois, o personagem começa a fazer coisas milagrosas, tais como: uma casa para os pais a qual após fincar uma estaca, a casa inteira se constrói sozinha.

O nascimento milagroso de um herói é uma reflexão sobre as faculdades inerentes a todos nós e suas conquistas retratam a realização de nosso potencial humano. A trajetória do herói, de acordo com (FORD, 2000, p. 52), é orquestrada por três movimentos: o herói é convocado a deixar o meio familiar e se aventurar por terras desconhecidas, lá ele encontra forças sobrenaturais e com a ajuda de um poder mágico obtém uma vitória sobre as forças do mal. Após enfrentar as forças do mal, segundo o autor, ele obtém uma dádiva e segue de volta para sua terra de origem.

\section{O ITINERÁRIO DO HERÓI}

Kiriku realiza o itinerário do herói, a princípio, quando abandona sua mãe e comunidade para desmascarar as artimanhas de Karabá. No começo, o herói impede que as crianças sejam levadas pela feiticeira quando as salva de uma armadilha planejada por Karabá em uma canoa vazia. Depois, Kiriku novamente volta a salvar as crianças de uma segunda armadilha feita em uma árvore na qual elas ficam aprisionadas.

O herói também salva a vida na aldeia quando descobre o segredo da fonte enfeitiçada. Ele se infiltra no duto da fonte seca e enfrenta um monstro responsável por beber toda a água da comunidade.

Ele rasteja, bate, geme e acaba chegando numa enorme caverna. Um monstro nojento e todo inchado aparece diante dele.

- É ele quem bebe a água da fonte! Pensa Kiriku. "Mas o que fazer? Sou tão pequeno!"

Kiriku sai, pega um ferro em brasa e retorna correndo. Ele crava o ferro na barriga do monstro! A besta inflada de água explode como um maremoto, inundando a caverna. Kiriku é levado pela onda da maré, ele se choca com as paredes e se afoga.

A água está de volta! (OCELOT, 2016, p.19-20).

De acordo com (FORD, 2000, p. 53), a descida simbólica às entranhas da fera é o momento central da aventura do herói, representa o útero do seu renascimento, a provação da sua transformação e o momento da sua reinvenção. $\mathrm{O}$ autor reitera que a sabedoria mítica africana sustenta que a vida humana corresponde a esse ciclo sem fim da natureza, que marca a vida de forma não linear, mas cíclica, do nascimento à morte, do mundo dos vivos ao mundo dos ancestrais, ao mundo dos ainda não-nascidos e novamente ao mundo dos vivos. 
Kiriku, ao vencer o monstro que consumia toda a água da comunidade, quis saber o motivo que levava Karabá a fazer tanta maldade. A mãe do herói disse que não conhecia o motivo e que somente o sábio na montanha que vivia do outro lado da montanha proibida poderia responder essa indagação. Ela disse que o sábio da montanha era o avô de Kiriku e que somente ele poderia dar as respostas necessárias ao protagonista. Então, Kiriku, com a ajuda da mãe, mergulha nas profundezas da terra e avança num labirinto de galerias, onde enfrentas desafios tais como um gambá que tenta impedi-lo a chegar a seu destino.

Ao conseguir sair do labirinto, o herói se confronta com um pássaro e consegue escapar de suas garras, porém, no momento em que o pássaro foge, um feroz javali aparece e se atira sobre Kiriku, mas o herói corre e pula nas costas do bicho e puxa suas orelhas, fazendo-o rosnar de dor. O protagonista consegue chegar até o sábio da montanha, seu avô, que afirma que Karaba se tornou má devido a um espinho envenenado enfiado em sua coluna vertebral. Kiriku, então, resolve arrancar o espinho das costas de Karaba. O herói mergulha no mundo dos ancestrais em busca de respostas e chega ao útero do mundo onde renasce como herói e com a dádiva da sabedoria consegue curar Karaba do feitiço, pois, conforme afirma Bachelard, por meio de um movimento "involutivo" começa a exploração dos segredos do devir, e em sua segunda obra, estuda os "sonhos de descida que são sonhos de retorno e aclimatação ou consentimento da condição temporal. Trata-se de desaprender do medo'" (DURAND, 2003, p.200).

É uma das razões pelas quais a imaginação da descida necessitará de
mais precauções que a da ascensão. Exigirá couraças, escafandros, ou
então o acompanhamento por um mentor, todo um arsenal de
máquinas e maquinações mais complexas que a asa. Porque a descida
arrisca-se, a todo o momento, a confundir-se e a transformar-se em
queda. Precisa continuamente se reforçar, como que para se
tranquilizar, com os símbolos da intimidade. Existe mesmo nas
precauções tomadas na descida, como veremos a propósito do
complexo de Jonas, uma sobredeterminação das proteções: protege-
mo-nos para penetrar no coração da intimidade protetora (DURAND,
2003, p.201).

Kiriku se arrisca com a ajuda do mentor para adentrar simbolicamente ao útero materno e se unir a Karaba, uma vez que prefere perder a vida do que perdêla. O herói decide roubar as joias da "feiticeira" para atraí-la até ele. Kiriku rouba as joias e as esconde ao pé da Grande Árvore. Karabá chega rapidamente na floresta e começa a cavar; por onde passa as plantas secam e morrem. Enquanto cava, Kiriku a observa e de repente se lança sobre a "feiticeira" e puxa o espinho de suas costas com os dentes. Karaba solta um grande grito e o feitiço se desfaz. Então pergunta ao herói como pode mostrar gratidão por seu grande feito. Ele a pede em casamento e Karaba diz que não podem se casar porque ele é apenas um garoto. Kiriku pede que ela o beije e após isso o menino se transforma em um grande guerreiro. Assim, ambos se unem.

O episódio anteriormente citado denota o que (ELIADE, 2000, p. 231) retrata como "o conjunto deusa-árvore, deusa- vinha com seu aparato de emblemas ideológicos e de animais heráldicos que representa este lugar como o centro do mundo", onde se encontra a fonte da vida, da juventude e da imortalidade. Neste 
centro, a Grande Deusa Karaba representa a personificação da fonte inesgotável da criação e também da destruição e através dela, Kiriku renasce como guerreiro.

Por outro lado, o conto de Kiriku pode também se intertextualizar com o mito de criação ioruba que narra, de acordo com Ford (2000), que no início dos tempos depois de os orixás terem provindo da entidade suprema despedaçada por Atunda, eles viviam num lugar acima do céu, uma terra celestial governada por Olorum (ou Òlódùmarè). As Divindades Primordiais, Obàtálá, Òrúnmìlà-Ifá e Esu, são seres de natureza complexa e que se encontravam junto do Ser Supremo no momento da criação do mundo. Portanto são auxiliares de Òlódùmarè para dar continuidade de sua obra na terra. Olódùmarè, com o auxílio de Obàtálá, Òrúnmìlá-Ifá e Esu, criou o Orun. Com a missão de dar continuidade à criação, as divindades primordiais Obàtálá, Òrúnmilá-Ifá e Esu desceram do Orun através de uma corrente de ferro e criaram a Cidade Santa de Ilè-Ifè, a partir das águas primordiais que se encontram abaixo do Orun. (SILVA, 2015, p.73) enfatiza que os iorubás concebem o mundo como formado por elementos físicos, humanos e espirituais. Os elementos físicos são divididos em dois planos de existência: ayê (terra) e orun (céu).

Ayê é também algumas vezes conhecido por isálayé, considerado como o domínio da existência humana, das bruxas, dos animais, pássaros, rios, etc. Orun, que é outras vezes conhecido como isalorun, é o lugar de Olódùmarè (O Deus Todo Poderoso), que é também conhecido como Òlórun, significando literalmente "o proprietário dos céus"; o òrun é também o domínio dos òrisà (divindades), que serão reconhecidas como representantes de Olódùmarè; e dos ancestrais.

\footnotetext{
A mitologia iorubá, como a mitologia de muitas outras culturas, reconhece um tempo no passado quando ambos, ayê e òrun, faziam parte do mesmo território, mas estavam separados somente por um portão controlado por um porteiro. [...]. Òrìsànla (deus da criação) era responsável pela modelagem dos seres humanos, enquanto que Òrúnmilá, também conhecido como Ifá (deus da divinação), foi encarregado com o uso da sabedoria para a interpretação do passado, presente e futuro, e também para a organização geral da terra. Como porta voz de outras divindades, Ifá é o depositário de todos os mitos e dogma moral das outras divindades. O povo Yorùbá crê que Òrúnmilá estava presente quando Olódùmarè (Deus todo poderoso) criou o céu e a terra. Portanto, Ifá conhece a história do céu e da terra e domina as leis físicas e morais com as quais Olódùmarè governa o universo. Por isso, Orunmilá é tido como sábio conselheiro, historiador e tutor da sabedoria divina. Por isso, entre seus nomes de honra está: Aquele que ensina alguém com sabedoria, como se fosse de sua família. A sabedoria da terra. O historiador da terra de Ifé (SILVA, 2015, p. 58).
}

Prandi ressalta que Òrúnmilá é o deus do oráculo (aquele que dá a resposta); e Exu é o mensageiro da comunicação entre o adivinho e Òrúnmilá e transporta as oferendas do consulente aos orixá. A divindade Obàtálá foi a primeira a receber de Olódùmarè a função de dar continuidade à criação. Depois de criada a terra, Òlódùmarè encarregou o camaleão de inspecionar o trabalho; ao retornar, o camaleão relatou que a terra estava firme, portanto, novas ações poderiam ser implementadas. "Após o relato do camaleão, Òlódùmarè deu a missão a Obàtálá de confeccionar a forma humana, mas o princípio da vida era e é inerente a ele, a Olódùmarè" (SILVA, 2015, p. 60) 
Silva (2015) reitera a simbiose existente entre Òrúnmilá e Òlódùmarè como resultado de uma missão restauradora do universo. A importância de Òrúnmìlá tem sua origem nos conhecimentos adquiridos ao testemunhar ao lado de Òlódùmarè a criação do mundo, e, deste então, somente ele, Òrúnmilá, se torna o responsável para impulsionar o princípio motor da energia vital. Por outro lado, Èsù (ou Exu) é uma arqui-divindade enviada pelo Ser Supremo ao mundo para ser o braço direito de Orunmilá-Ifá, sendo seu dever e função informá-lo dos acontecimentos na face da terra. Exu (èsù) é, a princípio, o agente especial de comunicação entre o céu e a terra, o inspetor geral que informa a Olódùmarè as ações das divindades e dos homens, observa e relata detalhadamente sobre o culto em geral e os sacrifícios em particular.

Nesse contexto, fazendo uma releitura do conto Kiriku e a feiticeira observase que o "Grande Sábio da Montanha" também representa de forma simbólica e mitologicamente a arqui- divindade Exu, uma vez que segundo (ORTIZ, 2011, p. 127), ele aparece como tradutor das palavras divinas e como "um intérprete das mensagens divinas que detém um poder de avaliação que lhe permite alterar o destino dos homens".

Exu é o orixá sempre presente, pois o culto de cada um dos demais orixás depende de seu papel de mensageiro. Sem ele orixás e humanos não podem se comunicar. Também chamado de Legba, Bará e Eleguá, sem sua participação não existe movimento, mudança ou reprodução, nem trocas mercantis, nem fecundação biológica. Na época dos primeiros contatos de missionários cristãos com os iorubas na África, Exu foi grosseiramente identificado pelos europeus como o diabo e ele carrega esse fardo até os dias de hoje (PRANDI, 2012, p. 20-21)

Assim, O Sábio "Exu" oferece respostas que permitem mudar o destino de Kiriku, já que ele explica ao herói que Karaba não é má, apenas ficou assim devido um espinho que lhe enfiaram nas costas. A mensagem do sábio foi essencial para determinar o destino de Kiriku e de toda a comunidade pois fez com que o herói salvasse Karaba, conseguisse unir-se a ela e levasse paz para a comunidade.

Por outro lado, Karaba pode representar simbólica e mitologicamente, la Mi Oxorongá e Kiriku, Orunmilá. Devido ao caráter heroico de guerreiro pode representar Xangô, e por outro lado, seu caráter bondoso e justo, representa Orunmilá, casado com la Mi. A mitologia africana narra que Ogum, Obatalá e Odu vieram do Orum. lam em direção à terra mas antes foram consultar Olodùmarè. Ogum apareceu na frente com o seu sabre, com seu fuzil e objetos para a guerra. Depois veio Obatalá com o poder de fazer tudo o que quisesse e por fim apareceu Odu (la Mi), esposa de Orunmilá e mãe de todos.

O deus Olodumaré deu poder a la Mi, mas pediu-lhe que tivesse moderação. Odu, porém, usou seu poder com imprudência e não obedeceu às ordens de Olodumaré. Um dia, então, Obatalá conseguiu enganá-la e Odu pode reconhecer que o homem, com astúcia e inteligência, tomou da mulher o seu poder.

O episódio de la Mi e Obatalá também se intertextualiza ao de Karabá e Kiriku, pois o herói com astúcia consegue livrar Karaba do feitiço, assim como a astúcia de Obatalá fez com que o poder de destruição de Odu fosse diminuído. Segundo a 
mitologia africana, la $\mathrm{Mi}$ (Odu) se casa com Orunmilá, porém, antes do matrimônio, o deus realizou oferendas para tê-la e prometeu a ela que o rosto da deusa nunca seria visto por suas outras esposas, assim como ela nunca seria caçoada por ele, pois o deus deveria ter respeito pelo poder superior de Odu em relação às outras mulheres. O sacrifício de Orunmilá e o respeito do deus pela superioridade de la Mi também pode ser comparado com a relação entre Kiriku e Karaba, pois o herói ofereceu a própria vida como sacrifício à deusa-feiticeira, assim como, ao beijá-la e sofrer, como consequência, uma metamorfose, revelou a superioridade do poder de Karaba sobre ele.

Prandi reitera que as lá Mi são nossas mães primordiais e também são feiticeiras, vida e morte ao mesmo tempo. Conhecem as fórmulas de manipulação da vida e são extremamente vingativas. Um dia, segundo a mitologia, antes do casamento de Odu com Orunmilá, o espírito de vingança das lá Mi atormentavam a raça humana. Então, as pessoas correram para a casa de Egum para serem salvas, porém Egum não foi capaz de salvá-las. Foram à casa de Oxalá, à casa de Xangô, à casa de Oiá, à casa de Obá, mas nenhum orixá foi capaz de protegê-los. Assim, os filhos dos homens suplicaram a Orunmilá que os salvasse e ele aceitou protegêlos; desse modo, Exu o ajudou a conquistar a paz com as lá Mi. Exu sabia do enigma delas. Foram feitas oferendas e Orunmilá conseguiu desvendar alguns enigmas feitos por elas e só assim e com a ajuda de Exu, ele conquistou a benevolência das Feiticeiras.

O episódio entre as lá Mi, Orunmilá e Exu também é representado simbolicamente pela intervenção do Grande Sábio da Montanha para desvendar o enigma da maldade de Karaba para Kiriku, recriando, assim, o mito de origem, ou seja, os tempos primordiais.

\section{A MITOLOGIA AFRICANA EM “A ÁRVORE DA CHUVA"}

O conto "A árvore da chuva" narra a história de um vilarejo situado em uma terra árida no meio do deserto. A terra era seca e não oferecia nada à aldeia; os homens tentaram arar os campos, procurando água cada vez mais fundo na terra, mas nada encontravam. "No pátio, perto das cabanas de barro, as mulheres teciam tapetes em folhas de tamareira para vender no mercado da cidade mais próxima" (LESTRADE, 2016, p. 7). Elas partiam pela manhã e voltavam a noite quando todos dormiam, seus pés ficavam feridos por terem viajado por tanto tempo, mas os sacos de arroz e as latas de água adquiridos com o dinheiro do trabalho aliviavam a fome e a necessidade no vilarejo.

Todos os dias os aldeões examinavam o céu no intuito de ver uma nuvem anunciando a chuva. Cada dia que passava, mais secava o poço e a safra de arroz era ameaçada, gerando o medo do futuro, porém, certa manhã, na pequena praça de terra vermelha germinou um broto de uma semente que ninguém havia plantado. Kodjo, o rapaz, ia para a escola quando percebeu a semente germinando e uma pontinha verde saindo do solo. Logo ele contou para toda a aldeia que se reuniu em torno do caule e todos tiveram dúvidas sobre que planta era aquela. 0 chefe disse que a planta alimentaria e saciaria a sede de todo o vilarejo se fosse bem cuidada. Assim, o garoto derramou as primeiras gotas de água na terra seca e a planta começou a se desenvolver. 
Alguns dias mais tarde, a planta parecia uma pequena árvore, estava do tamanho de uma pequena girafa. Com os seus ramos flexíveis lançados ao céu, ela era um verdadeiro milagre no meio do deserto. Os aldeões dançavam, agradecendo aos antigos e cantando encantamentos. Eles abraçavam seu tronco e depositavam ofertas a seus pés; óleo de dendê e pedras raras (LESTRADE, 2016, p. 12).

Após algumas semanas a árvore estava muito grande e crianças e mulheres começaram a fazer suas atividades debaixo dela. Certo dia a árvore começou a gotejar e dos seus ramos e folhas começou a chover grandes gotas de água. Assim, a árvore abundou a aldeia de água. Para homenagear a árvore da chuva os aldeões fizeram uma grande festa, porém, um dia veio um homem da aldeia vizinha que se admirou com a árvore e no dia seguinte voltou com dois baldes e começou a enchê-lo. O chefe, porém, não permitiu que ele pegasse água, mesmo sabendo que na aldeia vizinha havia fome e sede.

Na manhã seguinte, quando Kodjo foi regar a árvore da chuva viu que ela não estava mais no mesmo lugar, pois havia andado e parado entre as duas vilas. Ao cair da noite os aldeões das duas aldeias se encontraram debaixo da árvore, porém havia ódio entre as aldeias, por isso a árvore se calou. Passaram-se meses e a árvore permanecia calada, até que um dia uma mulher deu à luz debaixo da árvore e as mulheres do outro vilarejo levaram roupas e água e acolheram a criança como se fosse delas.

Assim, pouco a pouco os aldeões se falaram, conheceram-se e compartilharam as coisas entre si. Eles se uniram. Passaram a orar e cantar juntas a cada tarde até que numa noite quando ninguém mais esperava a árvore começou a chover.

A partir da narração da história acima é possível inferir vários pontos de vistas, entre eles o de que, para Mircea Eliade, a árvore representa um cosmos vivo em perpétua regeneração. Por isso a importância da árvore da chuva, uma vez que por meio de seu poder regenerador é capaz de suprir a sede dos vilarejos, pois é símbolo da vida, assim como do caráter cíclico da evolução cósmica; morte e regeneração que põe em comunicação três níveis do cosmos: o nível subterrâneo, a superfície da terra e as alturas, por meio dos seus ramos superiores; por isso essa árvore é vista como árvore da vida ou árvore cósmica, que carrega a regeneração perpétua por meio de seus frutos. Ela é responsável pela continuidade da sobrevivência dos vilarejos, desse modo, Mircea Eliade pressupõe que a fonte de vida se encontra concentrada na árvore.

O autor reitera que na tradição bíblica e cristã, de acordo com o relato de tentação no Gênesis, a árvore da vida pode tornar-se uma árvore da morte, dependendo do comportamento do ser humano. Assim, o mito bíblico se incorpora à narrativa em análise, uma vez que a árvore da chuva, ou melhor, a árvore da vida, torna-se árvore da morte a partir do momento em que as comunidades começam a competir e a se separar por causa do egoísmo de querer tê-la somente para si.

Eliade explica que no Islã as raízes da árvore da felicidade alcançam o último céu e seus ramos se extendem acima e abaixo da terra "A árvore se compara ao pilar que sustenta o templo e a casa, a coluna vertebral do corpo; as estrelas são frutos da árvore cósmica" (ELIADE, 2000, p. 124), por isso que no conto em análise, a árvore da chuva era "maior que as casas e grande como um elefante" (LESTRADE, 2016, p. 12). 
A árvore da chuva apresenta segurança sobre um plano espiritual e também pode representar a imagem de deuses. Ela apresenta vontade própria e pode locomover-se de um lado para outro pois é considerada uma árvore da vida com valor mítico que está "plantada no meio do paraíso e o rio de quatro braços a rodeia". Anuncia a salvação messiânica e a sabedoria de Deus". Como símbolo da vida, a árvore é protetora em razão de sua sombra, além de representar um símbolo feminino porque surge da terra mãe, sofre transformações e produz frutos. É também um símbolo da vida em todos os níveis. A árvore, segundo Eliade, se assimila à mãe e a um manancial, portanto é um arquétipo materno, transfigura a grande deusa-mãe pelo fato de ser protetora e acolhedora.

Sabe-se que a árvore da chuva é a habitação e incorporação de uma divindade, por isso representa a imagem de um microcosmo, árvore cósmica que Mircea Eliade descreve como: morada do deus da fertilidade e das ciências e lugar de repouso. Assim, a árvore cósmica tem um forte valor cosmológico e segundo a tradição indiana, o cosmos é representado por uma árvore gigante.

\begin{abstract}
Entre as articulações de conjunto árvore-cosmos- divindade há simetria, associação, fusão. Os deuses designados como deuses da vegetação são frequentemente representados em forma de árvore: Átis e o pinheiro, Osíris e o cedro, etc. Entre os gregos, Artemis está, por vezes, presente numa árvore. As vezes as imagens de Artemis eram enfeitadas com ramos. É conhecida a epifania vegetal de Dionisio, chamado, por vezes, Dionisio dendrites" (ELIADE, 2000, p. 226).
\end{abstract}

\title{
3. ARQUÉTIPO MATERNO: CONCEITOS E REPRESENTAÇÕES
}

De acordo com (JUNG, 2002, p.35), arquétipos são conteúdos do inconsciente coletivo. $\mathrm{O}$ arquétipo representa essencialmente um conteúdo inconsciente, o qual se modifica através de sua conscientização e percepção, assumindo matizes que variam de acordo com a consciência individual na qual se manifesta. 0 arquétipo é descrito por Jung como um conjunto de imagens psíquicas presentes no inconsciente coletivo, ou seja, representam a parte mais profunda do inconsciente humano.

A "anima não é alma no sentido dogmático, nem uma anima rationalis, que é um conceito filosófico, mas um arquétipo natural que soma satisfatoriamente todas as afirmações do inconsciente" (JUNG, 2002, p. 60). A anima não é a única característica do inconsciente, mas um de seus aspectos. Ela é concebida como uma parte feminina ctônica da alma. Assim, com o arquétipo da anima entramos no reino dos deuses, pois tudo o que é tocado pela anima toma-se incondicional, perigoso, tabu, mágico. Ela é a serpente no paraíso do ser humano inofensivo, cheio de bons propósitos e intenções. Ela convence com suas razões a não lidar com o inconsciente, pois isso destruiria inibições morais e desencadearia forças que seria melhor que permanecessem inconscientes.

Tratando-se da anima, estamos lidando com realidades psíquicas que até o momento nunca foram apropriadas pelo homem, uma vez que se mantinham fora de seu âmbito psíquico, sob a forma de projeções. Para o filho, a anima oculta-se no poder dominador da mãe e a ligação sentimental com ela dura às vezes a vida inteira, prejudicando gravemente o destino do homem ou, inversamente, 
animando a sua coragem para os atos mais corajosos. Para o homem da Antiguidade a anima aparece sob a forma de deusa ou bruxa:

O caráter imprevisível, travesso e muitas vezes maldoso, que caracteriza os espíritos míticos, como a ninfa ou a sereia, representa o outro lado de sua fascinante beleza, e isso é também uma particularidade da anima [...] enquanto o caráter elementar do Grande Feminino ameaça a dissolução do Eu e da consciência no inconsciente, o caráter mutacional da Anima, ao contrário, fascina, pondo a personalidade em movimento, em mudança e enfim em transformação [...] psicologicamente, se houver naufrágio do Eu, não é a Anima a diretamente responsável, mas a Grande Mãe que exerce sua dominação sobre ela (IWASHITA, 1991, p. 314-315).

Iwashita reitera que para C.G. Jung existem quatro estágios no desenvolvimento da Anima: o primeiro, simbolizado na figura de Eva, representa o relacionamento puramente instintivo e biológico, o segundo pode ser representado pela Helena de Fausto que personifica um nível romântico e estético que também é caracterizado por elementos sexuais; o terceiro estágio poderia ser exemplificado pela Virgem Maria, uma imagem que revela o amor à imensidão da devoção espiritual. O quarto estágio é simbolizado pela "Sapientia", a sabedoria capaz de transmitir a pureza e a santidade, a exemplo de Sulamita do Cântico dos Cânticos de Salomão.

Em "Kiriku e a feiticeira", a figura de Anima negativa de Karabá, prepondera no início da narrativa, porém, inconscientemente ela incentiva Kiriku a prosseguir na libertação de seu povo e dela mesma, portanto, a anima favorece na construção do "eu guerreiro" do herói, ao mesmo tempo em que a união do herói com Karabá representa um retorno ao "materno original”. Ela é a manifestação da Grande Mãe e intertextualiza com o caráter negativo de lá Mi. Este caráter elementar negativo aparece na projeção de uma infinidade de símbolos que não provém da relação mãe-criança, mas Neumann afirma que esse fenômeno (medo primordial com a projeção negativa da Grande Mãe) ocorre porque um dos fenômenos psíquicos fundamentais é que a consciência humana é experimentada como masculina.

O inconsciente e os impulsos aparecem simbolicamente como femininos e a consciência como masculina, ou seja, a razão e a sensatez sempre são vistas como características predominantemente masculinas. Em relação à consciência, "as fases do seu desenvolvimento se sucedem desde a dependência infantil do maternal, relação filho-amado com a Grande Mãe e finalmente a corajosa luta do herói masculino com a Grande Mãe" (IWASHITA, 1991, p. 228).

Assim, o autor afirma que a relação dialética do consciente com o inconsciente toma a forma simbólico-mitológica de confronto entre o feminino maternal e o masculino-nascido em que a crescente força do masculino corresponde à crescente força da consciência no desenvolvimento da humanidade, em que o masculino sempre prepondera sobre o feminino, por isso que o temor diante do caráter elementar negativo da grande mãe levou à guerra contra o matriarcado.

(IWASHITA, 1991, p.229), explica a formação da consciência do ser a partir das seguintes etapas: o filho nasce, se desprende do aconchego primordial, mas continua dependendo totalmente da mãe para sobreviver, depois, quando já crescido, o filho deseja o incesto com a mãe; não o incesto no nível sexual-genital, 
mas no nível simbólico, ou seja, a necessidade de voltar às raízes da vida, à união mística primordial, às raízes da consciência.

Assim, a luta do herói com a Grande Mãe é o símbolo da luta do consciente com o inconsciente. $\mathrm{O}$ autor reitera que o dragão com o qual o herói deve lutar possui as características masculinas e femininas ao mesmo tempo, ou seja, a luta com o dragão representa o conflito com os pais primordiais e a anima é aquela que movimenta e impele a transformação do herói.

Para (FORD, 2000, p.170), a busca pela deusa na África começa pela compreensão de que ela não é "simplesmente a face feminina de Deus, mas uma referência ao absoluto, ao eterno". Ford afirma que Deus é por definição indefinível, inominável e inclassificável. Para os achantis ele é Nyame "o espírito insondável", para os ngombes, Ngai, o "inexplicável" e para massais, o "desconhecido".

Ford afirma que Nyame dos achantis é as vezes descrita tanto como homem como uma mulher. Esta mesma ambiguidade ocorre com muitas outras divindades africanas, tais como: Nzambi, dos bacongos; Nana Buluku e Mawu-Lisa, dos fons; Ododuá e Obatalá dos iorubas. Porém, como deus ultrapassa o reino da dualidade, o antropólogo inglês Victor Turner concluiu que a cultura ndembu se fundava em um "princípio maternal ou feminino que permeia sociedade e natureza" (FORD, 2000, p.170).

O conceito da Grande Mãe provém da História das Religiões e abrange as mais variadas manifestações do tipo de uma Deusa-Mãe. (FORD, 2000, p.171), reitera que por meio da deusa, o indivíduo participa do "grande mistério da existência, no cosmos, na terra, da sociedade e do eu". O psicólogo israelense Erich Neumann, ao discutir a anatomia da deusa como um receptáculo simbólico que contém um universo santificado, ele relaciona o corpo da deusa "com uma montanha emergindo das águas primitivas da criação e observa que o útero da deusa é representado por símbolos como fenda, caverna, abismo, vale e profundezas" (FORD, 2000, p.172). O símbolo é obviamente um derivado do arquétipo materno:

Como todo arquétipo, o materno também possui uma variedade incalculável de aspectos. Menciono apenas algumas das formas mais características: a própria mãe e a avó; a madrasta e a sogra; uma mulher qualquer com a qual nos relacionamos, bem como a ama-deleite ou ama-seca, a antepassada e a mulher branca; no sentido da transferência mais elevada, a deusa, especialmente a mãe de Deus, a Virgem (enquanto mãe rejuvenescida, por exemplo Demeter e Core), Sofia (enquanto mãe que é também a amada, eventualmente também o tipo Cibele-Átis, ou enquanto filha-amada (mãe rejuvenescida); a meta da nostalgia da salvação (Paraíso, Reino de Deus, Jerusalém Celeste); em sentido mais amplo, a Igreja, a Universidade, a cidade ou país, o Céu, a Terra, a floresta, o mar e as águas quietas: a matéria, o mundo subterrâneo e a Lua; em sentido mais restrito, como o lugar do nascimento ou da concepção, a terra arada, o jardim, o rochedo, a gruta, a árvore, a fonte, o poço profundo, a pia batismal, a flor como recipiente (rosa e lótus); como círculo mágico (a mandala como padma) ou como cornucopia; em sentido mais restrito ainda, o útero, qualquer forma oca (por exemplo, a porca do parafuso); a yoni; o forno, o caldeirão; enquanto 
animal, a vaca, o coelho e qualquer animal útil em geral (JUNG, 2002, p. 91-92).

Jung reitera que esta enumeração indica os traços essenciais do arquétipo materno. Seus atributos são o "maternal"; a sabedoria e a elevação espiritual; o bondoso, o que cuida, o que sustenta, o que proporciona o crescimento, fertilidade e alimento; o lugar da transformação, do renascimento; o secreto, o oculto, o mundo dos mortos, o devorador, sedutor e venenoso, o apavorante e fatal.

(IWASHITA, 1991, p. 215) afirma que psicologicamente a figura da Grande Mãe não é algo que pertence somente às origens, pois ela é antes de tudo uma entidade viva na psique humana, de modo que o arquétipo da mãe e os traços da Grande Mãe em seus paradoxos são na alma humana os mesmos em nossos dias do que foram nos tempos míticos. Para o autor, "a grande mãe como arquétipo primordial do feminino na psique, pode ser considerada como a matéria-prima primordial, que dará origem à psique, ao eu, a consciência diferenciada" (IWASHITA, 1991, p. 216). Por isso, a distinção entre o eu do indivíduo e sua mãe, quer dizer, o inconsciente, está no início de toda tomada de consciência e a ambivalência do arquétipo da Grande mãe, ora como boa, ora como destruidora, provocando a disposição ambivalente do Eu.

\section{O GÊNERO MARAVILHOSO NOS CONTOS}

O maravilhoso, para (CHIAMPI, 1980, p. 47, apud MARÇAL, 2010), representa a "ausência do princípio de causalidade, que outorga aos acontecimentos extraordinários, aos personagens sobrenaturais, aos espaços imaginários e ao tempo fictício uma legitimidade" (MARÇAL, 2010, p. 18). Admite-se a existência de leis e regras que fogem ao conceito do que deva ser a "normalidade" à qual a natureza e o mundo se submetem. Marçal reitera que para a crítica, o discurso narrativo do Maravilhoso não problematiza a dicotomia entre o real e o imaginário, posto que a verossimilhança não está no centro das preocupações deste discurso.

O conto maravilhoso relata acontecimentos impossíveis de se realizar dentro de uma realidade empírica. A narrativa do Maravilhoso instala seu universo irreal sem causar qualquer questionamento, estranhamento ou espanto no leitor porque o irreal reforça os parâmetros que orientam o conhecimento não empírico da realidade de modo que um "traço distintivo do gênero Maravilhoso é o de introduzir uma fenomenologia meta-empírica negando completamente sua probabilidade de realizar-se no mundo concreto e material" (MARÇAL, 2010, p. 5).

No conto "Kiriku e a feiticeira" o que predomina é o gênero maravilhoso, uma vez que acontecimentos sobrenaturais fazem partem da comunidade do herói, pois desde o princípio da narrativa Kiriku fala com a mãe mesmo estando dentro de sua barriga e a mãe lhe diz que todo o povo teme Karaba, pois ela secou as fontes de água e devorou todos os homens da aldeia. Logo, o herói corre e sua mãe aceita tranquilamente o fato de seu bebê recém-nascido ser um guerreiro. Kiriku descobre que um monstro bebeu toda a fonte e ele crava um ferro na barriga do bicho que explode como um maremoto e devolve a água roubada da aldeia. Depois, Kiriku resolve ir ao encontro do sábio da montanha e consegue tirar o espinho das costas da "feiticeira-deusa", logo o feitiço a deixa e ele a pede em casamento. Karaba se assusta, mas com um pequeno beijo transforma Kiriku em um grande guerreiro e ambos voltam para a aldeia de mãos dadas. No início todos 
estranham Karaba e Kiriku mas logo os aceitam. Assim, é possível observar fenômenos sobrenaturais em toda a aldeia e a aceitação de tudo como natural, por isso a presença do Gênero maravilhoso na narrativa.

No conto "A árvore da chuva", no meio de uma comunidade escassa aparece essa árvore que é a metamorfose da árvore da vida, pois jorra rios de águas que saciam a necessidade da população. É uma árvore que surge no meio da seca e quando a ambição predomina no povoado em que aparece, ela decide migrar para outro lugar e resolve parar de jorrar água até que os vilarejos façam as pazes. Nesse conto também é perceptível o gênero maravilhoso, uma vez que a árvore tem vida própria, é a incorporação da deusa da vida e todos a aceitam como a solução dos problemas das comunidades.

\section{À GUISA DE CONCLUSÃO}

Kiriku, o herói, permanece ligado ao materno primordial. Volta à vida uterina, pois no mito original africano, domina o aspecto maternal positivo, assim, visto sob outro ponto de vista, Kiriku consegue salvar Karabá do feitiço e retoma seu aspecto materno positivo. Assim, Kiriku, retoma o arquétipo do par divino, a sizígia, a união da anima e do animus, princípios do feminino e do masculino, descritos por Jung, na medida em que retorna inconscientemente ao ventre materno quando se une a Karabá, porém seu arquétipo da Grande Mãe não é recalcado, mas confrontado, domesticando seu aspecto negativo, uma vez que Kiriku retira o veneno de Karabá e a domestica. A "feiticeira" representa a imagem ambivalente do arquétipo, configurado por seus dois lados: negativo e positivo e por meio da união com ela, Kiriku, personificação do deus Orunmilá se une a lá Mi e ambos, deus e deusa, se fundem e a partir daí o eterno se corporifica, por meio do princípio masculino e feminino da criação.

O encontro entre Kiriku e Karabá também representa a busca da psique pela unidade, "a integração dos opostos, cuja expressão máxima é o oposto masculinofeminino, simbolizado de maneira muito sugestiva na imagem da união sexual do homem e da mulher, do rei e da rainha, como muitas vezes aparecem nos símbolos da alquimia" (IWASHITA, 1991, p. 322). Assim, Orunmilá e Oduá, representados simbolicamente por Kiriku e karaba caracterizam, para o autor, o uróboros original, símbolo da totalidade englobante do inconsciente.

A busca da unidade masculino-feminino encontra-se em muitos mitos de criação africanos, tais como o mito de criação dos Fons que diz: No princípio havia um deus, Nana-Buluku que era ao mesmo tempo homem e mulher. Mawu foi originado de Nana-Buluku. Mawu era uma pessoa, mas possuía dois rostos; o de uma mulher cujos olhos pertenciam à lua (Mawu) e o outro de um homem, cujos olhos pertenciam ao sol (Lisa). Assim, Mawu governava a noite e Lisa governava o dia e desse modo, quando há um eclipse da lua com o sol, diz-se que Mawu copula consigo mesma. Desse modo, o par primordial masculino-feminino, no qual a mulher possui um papel ativo na criação é muito comum nos mitos africanos e no conto de Kiriku e Feiticeira, o papel ativo da feiticeira também fica evidente, uma vez que Kiriku não admite continuar seu percurso de herói sem a presença da "deusa-feiticeira" Karabá e ao puxar o espinho de suas costas o feitiço é desfeito e Karabá é convertida em deusa e não mais em feiticeira. 
Kiriku pede Karabá em casamento, mas como ainda é um menino eles não podem se casar. Então Kiriku pede à "deusa" que encoste seus lábios no dele, tornando-o um homem adulto guerreiro. Esse trecho da obra demonstra o papel ativo da "deusa" Karabá no desfecho da história, uma vez que ela é responsável também pela metamorfose sofrida pelo herói Kiriku que concede a ela o papel de protagonista, salvando-a do terrível feitiço que a assolava. Karabá transfigura o papel de deusa fálica, uma vez que Kiriku a fornece todos os meios para que seu poder de feiticeira se converta em "poder de deusa". Karabá transforma Kiriku em um homem maduro e também faz com que os homens da aldeia voltem a sua forma normal, pois antes haviam sido transformados em guardiões por Karabá.

Assim, a busca do eterno na integração feminino-masculina encontra-se na mitologia africana, assim como a imagem da deusa, da serpente e da morte aparecem sempre juntas, seja no paraíso do Éden, seja na mitologia africana, conforme demonstrada pela deusa-feiticeira Karabá, representação, ora da morte, ora da vida que ao integrar-se a Kiriku, revela o mistério da criação e da progressão da vida em comunidade.

Por outro lado, no conto A Árvore da Chuva a mitologia africana também está incorporada pois o conjunto água-árvore-deusa representa o arquétipo da Grande Mãe, fonte de vida e sua função primordial na criação, fato que intertextualiza com o mito da Grande Mãe África, assim como a imagem de lemanjá. Em ambos os contos, a comunidade necessita passar pelas mãos da "Grande Deusa" para que possa reconstruir tanto a vida em comunidade como o caráter do herói, baseado primeiramente na relação harmoniosa entre comunidades como primado fundamental da filosofia africana. A metamorfose dos mitos africanos de origem associada ao gênero maravilhoso tornou-se ponto de encontro adequado, uma vez que as narrativas encontram no imaginário a fonte de ensinamento de mitos que descontroem os cânones literários eurocêntricos. 


\title{
loruba myth, maternal archetype and marvellous role in Kiriku and the witch and The rain tree
}

\begin{abstract}
This article aimed to discuss the tales "Kiriku and the Witch" and the "Rain Tree" based on the theories of Jung and his concept of archetype (2002), Iwashita (1991) and Ford (2000) with the concepts of Great Goddess and the African mythology, Mircea Eliade (2000; 2007) and the concepts of religion and the symbolism, as well as the study of maternal symbols such as water and tree, among others, in order to investigate the African mythology incorporated in the stories under analysis, as well as the image of archetypes, especially the maternal archetype that transforms itself in the narratives as a fundamental trait for the formation of the hero who naturally acts through the marvelous role in the stories. The study is a qualitative character and also analyzes the theory of the marvellous genre based on the studies of Irlemar Chiampi (1980) and Marçal (2010). Therefore, the importance of the research is due to the fact that it discusses Afro-Brazilian themes that are so important for the increase of the historical and cultural collection in our day-to-day lives, based on children and young works that deepen our knowledge about Africa and its cultural diversity.
\end{abstract}

KEYWORDS: Myth. African culture. Marvellous genre. Tales. 


\section{REFERÊNCIAS}

CHEVALIER, Jean. GHEERBRANT, Alain. Dicionário de símbolos. Rio de Janeiro: José Olympio, 2001.

CHIAMPI, Irlemar. O realismo maravilhoso. São Paulo: Perspectiva, 1980.

ELIADE, Mircea. Tratado de história das religiões. São Paulo: Martins Fontes, 2000.

IWASHITA, Pedro. Maria e Iemanjá: análise de um sincretismo. São Paulo: Paulinas, 1991.

JUNG, C. G. Os arquétipos e o inconsciente coletivo. Petrópolis: Ed. Vozes, 2002.

LESTRADE, Agnés de. A árvore da chuva. Rio de Janeiro: Viajante do Tempo, 2016.

MARÇAL, Márcia Romero. A tensão entre o fantástico e o maravilhoso. Fronteiraz, n.3 p. 1-8, 2010.

OCELOT, Michel. Kiriku e a feiticeira. Rio de Janeiro: Viajante do Tempo, 2016.

ORTIZ, Renato. A morte branca do feiticeiro negro. São Paulo: Brasiliense, 1999.

PRANDI, Reginaldo. Mitologia dos orixás. São Paulo: Companhia das Letras, 2001.

SILVA, Sebastião. Fernando. A filosofia de ÒRÚNMìLÀ-IFÁ e a formação do bom Caráter. Dissertação apresentada ao Mestrado em Ciência da Religião da PUC- Goiás. Goiânia, 2015. 
Recebido: 31 jul. 2020

Aprovado: 20 set. 2020

DOI: $10.3895 /$ rl.v22n38.12911

Como citar: CASTRO, José Guilherme de Oliveira. PAES, Carla Regina Santos. SILVA, Camila Bastos Lopes da. Religião ioruba, arquétipo materno e gênero maravilhoso em Kiriku e a feiticeira e $A$ árvore da chuva. $R$. Letras, Curitiba, v. 22, n. 38, p. 119-135, set. 2020. Disponível em: <https://periodicos.utfpr.edu.br/rl>. Acesso em: XXX.

Direito autoral: Este artigo está licenciado sob os termos da Licença Creative Commons-Atribuição 4.0 Internacional. 